\title{
Guideline on Returning to Work after COVID-19 Infection
}

\author{
Mikhael Yosia*, Nuri Purwito Adi** \\ * Médecins Sans Frontières Operational Center Barcelona, Barcelona, Spain \\ **Department of Community Medicine, Faculty of Medicine Universitas Indonesia, Indonesia
}

\begin{abstract}
Work life after COVID-19 might never be the same again. After an economic crisis due to the pandemic, Indonesian government is applying large scale social restriction relaxation to allow companies to reopen. However, just after a few weeks of social relaxation, new clusters from offices are occurring. With many employees infected with COVID 19, concerns arise among employers; when is the best time for employees to get back to work after COVID-19 infection? This paper provides a general guideline to discontinue isolation in people with suspected or confirmed COVID-19 infection in non-healthcare establishments. According to the newest available evidence, commencing back to work should refer to a symptom-based strategy rather than test-based strategy. In all circumstances, universal health protocol should be practiced at all times to minimize widespread of transmission.
\end{abstract}

Keyword: COVID-19; occupational health; new normal 


\section{Introduction}

COVID-19 is a viral respiratory illness caused by a novel coronavirus called SARS-CoV-2 originated from Wuhan, China. On 12 March, the WHO declared COVID-19 a global pandemic. ${ }^{1}$ Globally, it affected more than 15 million cases with a $4 \%$ mortality rate. ${ }^{1}$ Until the current date, the number of reported cases in Indonesia is 97,286 with a case-fatality rate of $4.8 \% .{ }^{1}$ WHO classified Indonesia as having community transmission; meaning it experiences large outbreaks of local transmission.

The COVID-19 pandemic has caused devastating mortality and morbidity around the world. Since Indonesia's first two cases in March, the government initiated to limit COVID-19 transmission by implementing large scale social restriction, or commonly known as PSBB. Regional and local governments act in accordance to promote the regulation by restricting non-essential activities; public gathering, hotel and lodging services, limiting public transportation services, as well as closure of school and workplaces. Many companies are forced to temporarily close down to promote social distancing as a mean of preventing wider transmission of the virus. However, this caused an enormous social and economic impact. ${ }^{2}$ It is estimated that Indonesia's GDP will fall by 3.5\% from the large-scale social restrictions. ${ }^{3}$ Furthermore, the World Bank predicted the country's poverty rate might increase to $3.6 \%$ this year. ${ }^{3}$ In order to mitigate the crisis, the government is loosening the rules of social restriction, or known as the "new normal". ${ }^{4}$ This new normal is a change in behavior to continue carrying out normal activities, but coupled with the application of health protocols to prevent COVID19 transmission. ${ }^{5,6}$

In the phase of "new normal", many companies and public services are reopening and employees begin to return to work with staggered shifts. ${ }^{5}$ A workplace has the potential for transmission due to gathering of many people in one location. In July 2020, new clusters from offices in Jakarta are found just a few weeks after loosening the social restriction. ${ }^{7}$ This quick surge of cases occurred although new protocol only permit $50 \%$ of employee to come to work in a day. The root of the problem might come from poor air circulation, lack of social distancing, and undisciplined use of masks. Eventually, employees will commence back to work after isolation, however, this also cause many doubts by many employers with the fear of spreading the disease even more in office area. Therefore, a protocol is needed to protect both the employer and employees. In addition, collaboration between employers and local health authority is needed for disease control and reporting. To date, there is no guide on returning-to-work for employees, especially for those who were previously infected with SARS-CoV-2. This guideline provides a general recommendation (not for healthcare and nursing home settings) for employees to return to their jobs based on the newest available evidence. 


\section{COVID-19 among Employees}

An employee who have close contact with confirmed COVID-19 case or suffer from COVID-19 need to self-isolate at home or even become hospitalized, depending on the degree of symptoms. Safety measures and clear employee guidance is necessary when employers decide to bring people back to the workplace. It is essential that employers continue to base any plans for returning to the workplace on updated health guidance in relation to COVID-19.

\section{Discontinuation of Isolation}

A symptom-based strategy is used for ending isolation in employees with known COVID-19 infection. It was found that people are no longer infectious after 10 days in mild and moderate cases of COVID19. ${ }^{8}$ Employees with confirmed COVID-19 with mild symptoms and who are instructed to stay at home may end isolation under these conditions ${ }^{9}$ :

- At least 10 days after the first symptoms appeared

- At least 24 hours have passed since fever resolution without the use of fever-reducing medicines

- Other symptoms have improved

Asymptomatic people can discontinue isolation 10 days after the date of the first positive RT-PCR test for SARS-CoV-2 RNA. The use of test to end isolation is not needed, unless the person has other comorbidities or is immunocompromised. SARS-CoV-2 RNA may still be tested positive in the upper respiratory tract up to 3 months from the first onset ${ }^{10}$, however, it is unlikely that the virus is still infectious and would spread to others.

However, if the employee is only suspected to have COVID-19 with known exposure, without confirmed RT-PCR test, the number of quarantine days remains to be 14 days. ${ }^{9}$

\section{Return-to-work}

After a period of self-isolation, employers might need employees to go back to work. However, careful attention must be made to the health and safety of all employees, especially to those who had previously contracted COVID-19 infection.

\section{Symptom-based Strategy}

A symptom-based strategy is also used as a parameter for confirmed COVID-19 individuals, based on the severity of the illness ${ }^{11}$ : 
- $\quad$ Mild to moderate symptoms

Employees can return to work after 10 days of self-quarantine. The criteria for return to work in mild to moderate illness is as follows:

- At least 10 days have elapsed since symptoms first appear

- At least 24 hours have elapsed since last fever without the use of fever-reducing medicines

○ Other symptoms have improved

- $\quad$ Severe symptoms

Employees with severe symptoms were most likely to be cared for in the hospital. After hospital discharge, one might still need isolation at home until all symptoms improve. The time is longer in this group as patients in health care facilities have close contact with other vulnerable individuals. In point of fact, no patient had a replication-competent virus 15 days after onset of symptoms. ${ }^{12}$ The criteria for return to work in severe illness is as follows:

- At least 20 days have elapsed since symptoms first appear

- At least 24 hours have elapsed since last fever without the use of fever-reducing medicines

○ Other symptoms have improved

Employees with chronic respiratory disorder might need reassessment from the health provider to decide if the symptoms of COVID-19 have resolved. If employees are classified as vulnerable or at a risk when contracting COVID-19, employers might need to consider allowing them to continue to work from home.

Employees who have had close contact with COVID-19 patients and asymptomatic, should selfquarantine for 14 days. However, if the job of this employee is irreplaceable and critical for the workplace, employee may return to work but only limit travel from house-to-work and adhere to these practices ${ }^{13}$ :

- Regular monitoring of temperature and symptoms every 12 hours

- Wear a face mask at all times

- Promote social distancing include maintain a distance of 2 meters from others

- Regularly clean and disinfect workspace

- Maintain quarantine when not at the workplace for 14 days since exposure

If the employee becomes symptomatic through the course of the period, he/she must be sent home immediately and may only return to work after 10 days of isolation from the first onset of symptoms. 


\section{Test-based Strategy}

The use of test-based strategy with COVID-19 RT-PCR from nasopharyngeal, nasal or oropharyngeal sample for detection of viral RNA of SARS-CoV-2 RNA as a parameter for commencing work is not recommended as it causes several challenges; lack of timely access to testing, causing additional time of isolation and therefore causing further absenteeism. ${ }^{14}$ The test might still come up as positive, regardless of the absence of symptoms and the likelihood of transmission is extremely low. ${ }^{15,16}$ Furthermore, the availability of test might be limited in some areas. The use of serological assay to detect antibody of SARS-CoV-2 often cause false-positive result as the results may cross reach with other human coronaviruses. ${ }^{16}$ However, test-based strategy can be considered in these populations ${ }^{14}$ :

1. Employees who pose a risk of transmitting infection to vulnerable individuals at high risk for morbidity and mortality from COVID-19 (e.g., health care provider, nursing home provider)

2. Employees who are immunocompromised or under immune modulator drugs with possibility of prolonged viral shedding

A large-scale screening might not be economical and widely available, therefore returning to work criteria should refer to the last phase or symptoms of disease where symptoms have subdued.

In cases when employee comes in contact with a confirmed case of COVID-19 after undertaking isolation, another period isolation is not needed if the exposure occurred within six weeks of the last day of day isolation. If the contact occurs after a period of six weeks, the person might need to undergo another 10 days of self-isolation. ${ }^{14}$ In rare cases of symptoms relapse, employee might need to check with a healthcare provider for the possibility of other pathogen. After examination, if employee is conceived as non-infectious, a letter from public healthcare provider can be given so the person can safely return to work. ${ }^{17}$

\section{Contact with COVID-19 at Work}

In situation where there is a case of COVID-19 at work, employers should notify all employees the possibility of COVID-19 infection. Employees who had close contact must self-isolate at home for 14 days, keep tract of symptoms, follow local guidelines. ${ }^{18}$ Employees whose role are irreplaceable and still go to office should be symptom free and wear facemask at all times. ${ }^{19}$ Employees who are not exposed should still monitor symptoms and if present they are required to stay home.

\section{Employees with Sick Family Member}


Employees who have close contact with a confirmed COVID-19 infection at home should stay home for 14 days after exposure. ${ }^{20}$ Testing is recommended for all close contacts. ${ }^{21}$ The test recommended is a swab test to detect current infection of COVID-19, not antibody test. ${ }^{22}$ After isolation, he/she can return to work and continue with universal health precautions.

\section{Routine self-monitoring of symptoms}

Self-assessment of symptoms and temperature is essential after employee return to work. Hand and respiratory hygiene, social distancing and the use of a face mask are obliged. If respiratory symptoms recur or worsen after 10 days of isolation, employee should seek re-evaluation with local health providers.

\section{Prevention and Reduce Transmission among Employees}

Employees must be educated on preventive measures to reduce the risk of transmission of the disease. These include ${ }^{17,23}$ :

- Use of face covering

- Avoid touching eyes, nose, mouth

- Perform handwashing with water and soap wherever possible, if not available, use alcoholbased hand rub with a minimum 60 percent alcohol

- Avoid close contact with people suffering from acute respiratory tract illness

- Cover mouth and nose when sneezing using tissue of inside elbow, immediate disposal of used tissue and wash hands with soap

- Avoid sharing work tools

- Social distancing by avoiding large gathering and maintaining distance of at least 2 meters from others

- Stay home if employees have acute respiratory tract symptoms

\section{Use of Facemask}

After returning to work, facemask must be used until all symptoms have disappeared. A cloth mask is used to prevent spreading respiratory secretion when the person is talking, sneezing or coughing, however not considered as personal protective equipment (PPE) as it does not protect the wearer from external environment. ${ }^{24}$ The use of medical mask is reserved for people with respiratory symptoms and health care provider due to limited supply. ${ }^{25}$

\section{Return-to-work for the General Population}


For the general population who were previously working from home, return to workplace can be commenced gradually from not susceptible workers (employees $<50$ years old without underlying disease), middle-aged workers (employees 50-60 years old without underlying disease), workers aged > 60 years old without underlying disease, and finally susceptible workers. ${ }^{26}$ Employees who live with people at risk might not be able to return as quickly to normal employment, therefore, individual approach must be taken into notion. Local transmission rate may differ in different regions, for that reason, employers must strategize the plan carefully when reopening. Each company's scheme may be unique based on location, type of commodity, number of employees and the ability to provide safe health protocols for everyone.

\section{Closing remarks}

COVID-19 is an ever-changing disease, guidelines may need to be reviewed and changed accordingly to current updates and current status of the local epidemic. As the number of cases keeps on increasing in Indonesia, people are advised to still practice social distancing and refrain from large group meetings. Additional guidelines focusing on high-risk workers who work in a health institution and nursing homes may be needed as they will need a definitive noninfectious state to minimize transmission. Given that the priority of every company is a safe return of employees, it is important for both employers and employees to abide to governmental decisions and work in collaboration with local occupational health institutions.

\section{Conflict of Interest}

Authors of this study declares no conflict of interest.

\section{Acknowledgement}

Department of Community Medicine, Faculty of Medicine Universitas Indonesia. 


\section{References}

1. World Health Organization. Coronavirus Disease 2019 (COVID-19) Situation Report. World Health Organization; 2020:16. https://www.who.int/docs/default-source/coronaviruse/situationreports/20200726-covid-19-sitrep-188.pdf?sfvrsn=f177c3fa_2

2. Nicola M, Alsafi Z, Sohrabi C, et al. The socio-economic implications of the coronavirus pandemic (COVID-19): A review. Int J Surg Lond Engl. 2020;78:185-193. doi:10.1016/j.ijsu.2020.04.018

3. Akhlas, Adrian Wail. Indonesia's economy may shrink 3.5\% if PSBB last for 4 months: World Bank. The Jakarta Post. https://www.thejakartapost.com/news/2020/06/02/indonesiaseconomy-may-shrink-3-5-if-psbb-last-for-4-months-world-bank.html. Published June 3, 2020. Accessed July 29, 2020.

4. Arkyasa, Mahinda. Jokowi Orders PSBB Relaxation in Economic Areas. Tempo. https://en.tempo.co/read/1349771/jokowi-orders-psbb-relaxation-in-economic-areas. Published June 4, 2020. Accessed July 29, 2020.

5. Kementrian Kesehatan Republik Indonesia. Protokol Kesehatan Bagi Masyarakat Di Tempat Dan Fasilitas Umum Dalam Rangka Pencegahan Dan Pengendalian Corona Virus Disease 2019 (COVID-19). Kementrian Kesehatan Republik Indonesia; 2020. https://covid19.go.id/p/regulasi/keputusan-menteri-kesehatan-nomor-hk0107menkes3822020

6. WH, Fajar. Mengenal Konsep New Normal. Portal Informasi Indonesia. Published May 31, 2020. Accessed July 28, 2020. https://indonesia.go.id/ragam/komoditas/ekonomi/mengenal-konsepnew-normal

7. Daftar 59 Klaster Kantor Jakarta, 375 Positif Corona. CNN Indonesia. https://www.cnnindonesia.com/nasional/20200728075848-20-529586/daftar-59-klaster-kantorjakarta-375-positif-corona. Published July 28, 2020. Accessed July 30, 2020.

8. Wölfel R, Corman VM, Guggemos W, et al. Virological assessment of hospitalized patients with COVID-2019. Nature. 2020;581(7809):465-469. doi:10.1038/s41586-020-2196-х

9. Centers for Disease Control and Prevention. Ending Home Isolation Interim Guidance. Published July 20, 2020. https://www.cdc.gov/coronavirus/2019-ncov/hcp/disposition-in-homepatients.html 
10. Li N, Wang X, Lv T. Prolonged SARS-CoV-2 RNA shedding: Not a rare phenomenon. J Med Virol. Published online April 29, 2020. doi:10.1002/jmv.25952

11. Centers for Disease Control and Prevention. Return-to-Work Criteria. Centers for Disease Control and Prevention. Published July 17, 2020. https://www.cdc.gov/coronavirus/2019ncov/hcp/return-to-work.html

12. van Kampen JJA, van de Vijver DAMC, Fraaij PLA, et al. Shedding of infectious virus in hospitalized patients with coronavirus disease-2019 (COVID-19): duration and key determinants. medRxiv. Published online January 1, 2020:2020.06.08.20125310. doi:10.1101/2020.06.08.20125310

13. New York Department of Health. Interim Guidance for Public and Private Employees Returning to Work Following COVID-19 Infection or Exposure. New York Department of Health; 2020. https://coronavirus.health.ny.gov/system/files/documents/2020/06/doh_covid19_publicprivatee mployeereturntowork_053120.pdf

14. Rhode Island Department of Health. Discontinuing Isolation after Recovery from COVID-19 and Interpretation of COVID-19 Polymerase Chain Reaction (PCR) Test Results. https://health.ri.gov/publications/guidance/Discontinuing-Isolation-After-Recovery-FromCOVID-19-And-Interpretation-Of-PCR-Test-Results.pdf

15. Deeks J, Dinnes J, Takwoingi Y, et al. Antibody tests for identification of current and past infection with SARS-CoV-2. Cochrane Database Syst Rev. 2020;(6). doi:10.1002/14651858.CD013652

16. Lisboa Bastos M, Tavaziva G, Abidi SK, et al. Diagnostic accuracy of serological tests for covid19: systematic review and meta-analysis. The BMJ. 2020;370:m2516. doi:10.1136/bmj.m2516

17. New Zealand Ministry of Health. Updated Advice for Health Professionals: Novel Coronavirus (COVID-19). New Zealand Ministry of Health; 2020:18. https://www.health.govt.nz/ourwork/diseases-and-conditions/covid-19-novel-coronavirus

18. Kementrian Kesehatan Republik Indonesia. Panduan Pencegahan Dan Pengendalian Corona Virus Disease 2019 (COVID-19) Di Tempat Kerja Perkantoran Dan Industri Dalam Mendukung Keberlangsungan Usaha Pada Situasi Pandemi. Kementrian Kesehatan Republik Indonesia Accessed August 1, 2020. http://hukor.kemkes.go.id/uploads/produk_hukum/KMK_No_HK_01_07-MENKES-3282020_ttg_Panduan_Pencegahan_Pengendalian_COVID-19_di_Perkantoran_dan_Industri.pdf 
19. Centers for Disease Control and Prevention. Suspected or Confirmed Cases of COVID-19 in the Workplace. Coronavirus Disease 2019 (COVID-19). Published July 11, 2020. Accessed August 1, 2020. https://www.cdc.gov/coronavirus/2019-ncov/community/general-business-faq.html

20. Gao Z, Xu Y, Sun C, et al. A systematic review of asymptomatic infections with COVID-19. J Microbiol Immunol Infect. Published online May 15, 2020. doi:10.1016/j.jmii.2020.05.001

21. Centers for Disease Control and Prevention. Contact Tracing for COVID-19. Coronavirus Disease 2019 (COVID-19). Published July 22, 2020. https://www.cdc.gov/coronavirus/2019ncov/php/contact-tracing/contact-tracing-plan/contact-tracing.html

22. Centers for Disease Control and Prevention. Overview of Testing for SARS-CoV-2. Coronavirus Disease 2019 (COVID-19). Published July 17, 2020. Accessed August 1, 2020. https://www.cdc.gov/coronavirus/2019-ncov/hcp/testing-overview.html

23. Centers for Disease Control and Prevention. Interim Guidance for Businesses and Employers Responding to Coronavirus Disease 2019 (COVID-19). Centers for Disease Control and Prevention; 2020. Accessed July 27, 2020. https://www.cdc.gov/coronavirus/2019ncov/community/guidance-businessresponse.html?CDC_AA_refVal=https\%3A\%2F\%2Fwww.cdc.gov\%2Fcoronavirus\%2F2019ncov\%2Fspecific-groups\%2Fguidance-business-response.html

24. World Health Organization. Advice on the Use of Masks in the Context of COVID-19: Interim Guidance, 5 June 2020. World Health Organization; 2020.

25. World Health Organization. Rational Use of Personal Protective Equipment (PPE) for Coronavirus Disease (COVID-19): Interim Guidance, 19 March 2020. World Health Organization; 2020.

26. Rueda-Garrido JC, Vicente-Herrero MT, del Campo MT, et al. Return to work guidelines for the COVID-19 pandemic. Occup Med. 2020;70(5):300-305. doi:10.1093/occmed/kqaa099 